\title{
Strasbourg Is Venue for 1994 E-MRS Spring Meeting
}

The European Materials Research Society (E-MRS) will hold its 1994 Spring Meeting May 24-27 at the Palais de L'Europe, Strasbourg, France. General conference chairman Ian W. Boyd (University College London) said that eight symposia and an equipment exhibit will be featured in the four-day program. Topics include thin films, photorefractive materials, high-temperature electronics, porous silicon, advanced materials education, and materials for cultural preservation. The deadline for abstracts is March 10, 1994. Information about the meeting is available from the E-MRS secretary: Paul Siffert, 1994 E-MRS Spring Meeting, Lab PHASE, CRN, 23 rue du Loess, BP-20, 67037 Strasbourg Cedex, France; phone 33-88-10-65-43, fax 33-8810-62-93.

\section{Symposium A: Amorphous Insulating Thin Films II}

A follow-up to its predecessor from the 1992 MRS Fall Meeting in Boston, this 3.5-day symposium will focus on the materials science aspect of insulators used in micro-and macroelectronics, concentrating on applications for flat screen displays, memory cells, and thin-film transistors, in addition to more general materials topics. Chairs: R.A.B. Devine, CNET/France Télécom, France; phone 33-76-76-4229, fax 33-76-90-3443. W.L. Warren, Sandia National Laboratories, USA; phone (505) 272-7618/7628, fax (505) 272-7304.

\section{Symposium B: Laser and Photochemical Processing of Thin Films and Surfaces}

This symposium will study the production of photons from existing lasers and lamps, and also the development of new photon sources, covering all facets of the effects of photons on etching, deposition, doping, modification and patterning of surfaces and thin films, and mechanisms and modeling of processes involved. Chairs: U.K.P. Biermann, Philips Research Labs, The Netherlands; phone 31-40-742430, fax 31-40-742081. J. Dieleman, DSA Consultants, The Netherlands; phone 31-4904-13682, fax 31-40-742081. P. Hess, Physical Chemistry Institute, Germany; phone 49-6221565205, fax 49-6221-563199.

\section{Symposium C: Photorefractive Materials}

Scientists from all areas of photorefractive materials will discuss progress in the field. Topics include new photorefractive materials; defects; doping; modification of material properties; physical, electrical, and optical characterization; and novel devices and applications. Chairs: G. Roosen, Institut d'Optique-CNRS, France; phone 33-16-94-16855, fax 33-1694-13192. O. Schirmer, University of Osnabrück, Germany; phone 49-541-9692630, fax 49-541-969-2670. F. AgulloLopez, Universidad Autonoma de Madrid, Spain; phone 34-1-397-4780, fax 34-1-397-8579. A. Kost, Hughes Research Laboratories, USA; phone (213) 317-5280, fax (213) 317-5483.

\section{Symposium D: Organic Materials for Electronics}

The materials science of polymers for electronic and optical applications will be covered, with special attention given to the interfacial aspects crucial to device technologies. Topics include conjugated main-chain or side-chain polymers as active components, methods for characterizing metal/organic interfaces, chemical and electronic structure, and metals for creating well defined metal/organic interfaces. Chairs: J.L. Brédas, Universite de Mons, Belgium; phone 32-65-373356, fax 32-65-373054. W.R. Salaneck, Linköping University, Sweden; fax, 4613-137568. G. Wegner, Max-PlanckInstitut für Polymerforschung, Germany; phone 49-6131-379130; fax 49-6131379100 .

\section{Symposium E: High-Temperature Electronics}

This symposium will summarize progress in developing new materials and device technologies for electronic circuits that operate at temperatures above $150^{\circ} \mathrm{C}$. Topics include silicon-on-insulator (SOI) and related technologies, GaAs and other III/V compounds, SiC, diamond films, growth techniques, reliability, modeling, and applications. Chairs: J.P. Colinge, Université Catholique de Louvain, Belgium; fax 32-10-478667. K. Fricke, Institut für Hochfrequenztechnik, Germany; fax 49-6151-164367. V. Krozer, Institut für Hochfrequenztechnik, Germany; phone 49-6151-163562, fax 496151-164367. J.L. Robert, Université Montpellier II, France; phone 33-67-1437-94, fax 33-67-14-37-60.

\section{Symposium F: Porous Silicon and Related Materials}

The growth, structure, and properties of porous silicon will be studied. The program will cover structure and properties of porous silicon, luminescence mechanisms, electrical properties of porous $\mathrm{Si}$, and micromechanical and sensor applications of porous materials, among other topics. Chairs: R. Herino, Université Joseph-Fourier, France; phone 33-76-51-47-33, fax 33-76-51-45-44. W. Lang, Fraunhofer Institute, Germany; phone 49-89-54-75-92-26, fax 49-89-54-7591-00.

\section{Symposium G: Workshop on Advanced Materials Education}

Leading materials science educators, researchers, and industrialists will gather at this 2.5-day symposium to create a framework for developing a European materials science education roadmap for the early 21 st century. The long-range goal will be the development of a skilled and multidisciplinary work force that will ensure Europe's competitive advantage in advanced materials. Keynote talks will highlight such areas as educational strategies in materials science and engineering; standardization of materials science curricula; university/industry cooperation in curricula design; and international, European, and national policies in MS\&E education. Chairs: G.M. Crean, National Microelectronics Research Centre, Ireland; phone 35-321276871, fax 35-32-1270271. J-P. Massué, Council of Europe, France; phone 33-8841-26-14, fax 33-88-41-27-87.

\section{Symposium H: Materials for Cultural Preservation}

This symposium, presented by the European Network PACT (Sciences and Techniques for Cultural Heritage), will cover the following themes: multimedia designed to educate the general public about conservation issues in cultural tourism; methods for conserving rare documents which could be harmed by travel and exhibition; new materials for conservation-past experiences and aging tests; relationships between surface chemistry research and conservation methods relative to the surfaces of objects and monuments. Chairs: T. Hackens, Institut Supérieur d'Archéologie et Histoire de l'Art, Belgium; phone 32-1047-48-80/22-22, fax 32-10-47-25-79. Y. Siotis, National Research Centre, Greece; phone 30-1-651-30-21, fax 30-1-651-05-94. $\mathrm{S}$. Zoppi, CNR, Rome, Italy, phone 39-649-93-37-14; Torino, phone 39-11-81-74064, fax 39-11-81-25-815.

Proceedings of the E-MRS 1994 Spring Meeting will be published by Elsevier Science Publishers, North Holland. 